ISSN 0258-7122

Bangladesh J. Agril. Res. 40(2): 217-227-00, June 2015

\title{
EFFECT OF PHOSPHORUS IN REDUCING ARSENIC AVAILABILITY IN SOILS AND ARSENIC UPTAKE BY MAIZE
}

\author{
HABIB MOHAMMAD NASER ${ }^{1}$, SARMIN SULTANA ${ }^{2}$ \\ SOHELA AKHTER ${ }^{3}$ AND ROWSHAN ARA BEGUM ${ }^{4}$
}

\begin{abstract}
A pot experiment was carried out in the net house of Soil Science Division of Bangladesh Agricultural Research Institute (BARI), Joydebpur Gazipur on 16 March 2010 and 12 January 2011 with a view of study the effect of P addition to As-contaminated soils and the consequences on As uptake of maize (Zea mays L.) plants. Experiments were conducted in consecutive two years. Arsenic was added to the pots at the rates of 0,20 and $30 \mathrm{mg} \mathrm{kg}^{-1}$, and $\mathrm{P}$ at 0,30 and $60 \mathrm{mg}$ $\mathrm{kg}^{-1}$. Thus there were seven treatment combinations, i.e., $\mathrm{As}_{0} \mathrm{P}_{0}, \mathrm{As}_{20} \mathrm{P}_{0}, \mathrm{As}_{30} \mathrm{P}_{0}$, $\mathrm{As}_{20} \mathrm{P}_{30}, \mathrm{As}_{20} \mathrm{P}_{60}, \mathrm{As}_{30} \mathrm{P}_{30}$, and $\mathrm{As}_{30} \mathrm{P}_{60}$. Phosphorus fertilization increased total As uptake, but the increase was restricted to the root. As concentration of root was much higher than that of shoot. As concentrations in shoot and root were positively correlated $(r=0.913, r=0.975 ; \mathrm{P}<0.01)$ in 2010 and 2011, respectively, and plant As was positively correlated to the plant $\mathrm{P}$ in shoot $(r=$ 0.883 and $0.875 ; \mathrm{P}<0.01)$ and in $\operatorname{root}(r=0.829, \mathrm{P}<0.05$ and $0.917 ; \mathrm{P}<0.01)$. The plants took up much greater amounts of $\mathrm{P}$ than As. Although it is well known that phosphate inhibits arsenate uptake (Wang et al., 2002), but it is highlighted the role of $\mathrm{P}$ fertilization to increase As uptake in maize plants. The results presented here indicate $\mathrm{P}$ supply may effect in higher As allocation to the plant parts, which has practical application in soil-crop systems. These findings could have important implications for human health and agricultural systems, since it may reduce As contamination through the consumption of crops (phytoextraction) grown on contaminated soils.
\end{abstract}

Keywords: Soil, arsenic, phosphorus, uptake, mize.

\section{Introduction}

There is increasing concern worldwide regarding the contamination of soil with arsenic (As), and the potential risk to human and environmental health arising from such contamination (Smith et al. 1998). Arsenic is a toxic and carcinogenic element that occurs widely in soil environments around the world. Soil contamination with As occurs through both natural and anthropogenic pathways. In recent years, As pollution has become a major public concern in many countries (Smith and Naidu, 1998). Remediation of As contaminated soil and

${ }^{1}$ Principal Scientific Officer, Soil Science Division, Bangladesh Agricultural Research Institute (BARI), Joydebpur, Gazipur-1701, ${ }^{2}$ Scientific Officer, Soil Science Division, BARI, Joydebpur, Gazipur-1701, ${ }^{3}$ Principal Scientific Officer, Soil Science Division, BARI, Joydebpur, Gazipur-1701, ${ }^{4}$ Chief Scientific Officer, Soil Science Division, BARI, Joydebpur, Gazipur-1701, Bangladesh. 
water is necessary for protecting both human life and agricultural production. There are a variety of physical_chemical technologies for remediation of Ascontaminated sites (U.S. Environmental Protection Agency, 1992.)

Arsenate, the dominant form of As in aerobic conditions, is taken up by plants via the phosphate transport systems because of the chemical similarity between arsenate and phosphate (Dixon, 1997). Phosphorus (P), that is a chemical analogue of As (Adriano, 2001) and competes with As in plant uptake (Meharg and Macnair, 1992). Thus, the relative plant $\mathrm{As}$ and $\mathrm{P}$ concentration and distribution determine the efficiency of As removal from the system (Santos et al. 2010). Since $P$ and As are chemical analogues, it is important to examine both of them.

In fact, As is not an essential element for plants, but interferes with plant metabolism, inhibiting plant growth and crop yield (Abedin et al., 2002). The effect of $\mathrm{P}$ on the sorption/desorption of As in soil environments has received great attention, especially when $\mathrm{P}$ is used as a crop fertilizer (Peryea, 1998). Gultz et al. (2005) reported that $\mathrm{P}$ availability and $\mathrm{P}$ demand, which are plant specific, have to be taken in account to predict uptake of As by crop plants. Much of the research on As in grain crops have focused on rice (Oryza sativa L.) (Abedin et al., 2002; Williams et al. 2005; Rahman et al. 2007). The work that has been conducted on maize is less extensive, with limited information regarding As uptake and partitioning between different plant part. Therefore, it is important to evaluate the effects of $\mathrm{P}$ fertilizer applications on plant As accumulation; to quantify As concentration in root and shoot; and to evaluate the role of $\mathrm{P}$ and maize plant to mitigate As contamination.

\section{Materials and Method}

A pot experiment was carried out in the net house of Soil Science Division of Bangladesh Agricultural Research Institute (BARI), Joydebpur Gazipur on 16 March 2010 and 12 January 2011 with a view of study the effect of P addition to As-contaminated soils and the consequences on As uptake of maize plants. The sandy clay loam soil was used in pot. The physical and chemical properties of the initial soil which was used in pot are presented in Table-1.

Experiments were conducted in consecutive two years. The experiment consisted of a total of 21 plastic pots, each containing $10 \mathrm{~kg}$ soil. Maize (Zea mays var. BARI hybrid Maize-7) seeds were sown directly in pots at a density of 6 seeds per pot. Fourteen days after sowing the seedlings were thinned to 2 plants per pot. All the pots were fertilized two days before sowing with $\mathrm{N}: 90 \mathrm{mg} \mathrm{kg}^{-1}$ soil, $\mathrm{K}$ : $140 \mathrm{mg} \mathrm{kg}^{-1}$ soil, $\mathrm{S}: 30 \mathrm{mg} \mathrm{kg}^{-1}$ soil, $\mathrm{Zn}: 2 \mathrm{mg} \mathrm{kg}^{-1}$ soil, $\mathrm{B}: 1 \mathrm{mg} \mathrm{kg}^{-1}$ soil. Urea, MoP, gypsum, zinc sulphate monohydrate $\left(\mathrm{ZnSO}_{4} \cdot \mathrm{H}_{2} \mathrm{O}\right)$ and boric acid were used as a source of $\mathrm{N}, \mathrm{K}, \mathrm{S}, \mathrm{Zn}$ and $\mathrm{B}$, respectively. Arsenic was added to the pots at the rates of 0,20 and $30 \mathrm{mg} \mathrm{kg}^{-1}$, and $\mathrm{P}$ at 0,30 and $60 \mathrm{mg} \mathrm{kg}^{-1}$. Thus 


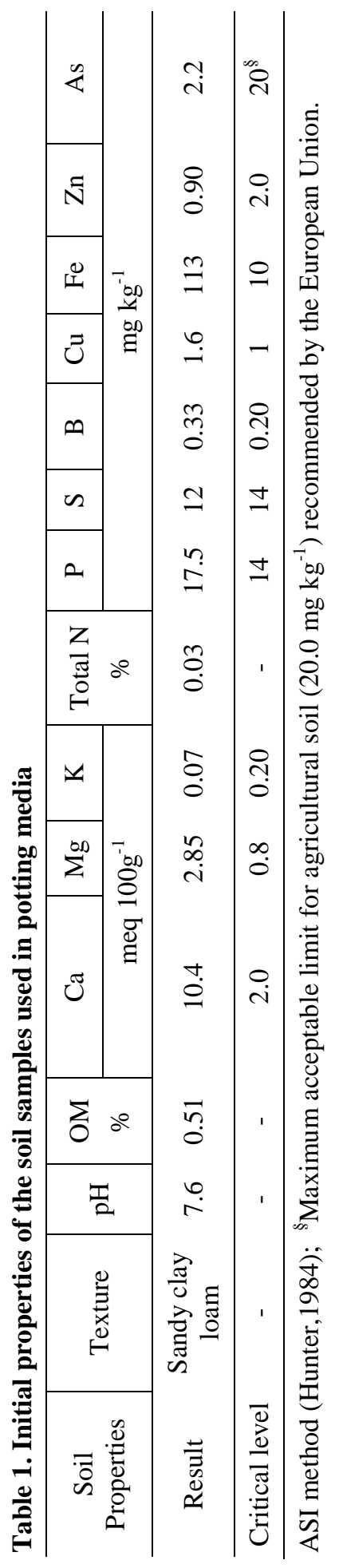


there were seven treatment combinations, i.e., $\mathrm{As}_{0} \mathrm{P}_{0}, \mathrm{As}_{20} \mathrm{P}_{0}, \mathrm{As}_{30} \mathrm{P}_{0}, \mathrm{As}_{20} \mathrm{P}_{30}$, $\mathrm{As}_{20} \mathrm{P}_{60}, \mathrm{As}_{30} \mathrm{P}_{30}$, and $\mathrm{As}_{30} \mathrm{P}_{60}$, in three replications. Arsenic and $\mathrm{P}$ were added as $\mathrm{As}_{2} \mathrm{O}_{3}$ and $\mathrm{Ca}\left(\mathrm{H}_{2} \mathrm{PO}_{4}\right)_{2}$, respectively, in solutions. Doses of fertilizer elements were determined as per the Fertilizer Recommendation Guide (BARC 2005). All fertilizers were added as solutions and thoroughly mixed with the soil. Nitrogen was applied in two equal splits, the first split before sowing and the remaining splits at 8-10 leaf of plants after sowing. Soil moisture was maintained by periodically adding equal quantity of water in each plastic pot.

The crop was harvested at 60 and 80 days following seeding for 2010 and 2011, respectively, when it had attained reproductive maturity (before flowering). Soil was removed from the roots by careful and repeated washing in water. Shoots and roots were washed with tap water and then rinsed twice with deionized water. Arsenic and $\mathrm{P}$ concentrations were measured in the roots and shoots samples.

\section{Preparation and preservation}

After delivery to the laboratory, all samples were washed in fresh running water to eliminate dust, dirt, possible parasites or their eggs and then were again washed with deionized water. The clean samples were air-dried and placed in an electric oven at $65^{\circ} \mathrm{C}$ for $72-96 \mathrm{~h}$ depending on the sample size. The dry samples were homogenized by grinding using a ceramic coated grinder. The final samples were kept in labeled polypropylene containers at ambient temperature before analysis.

\section{Digestion and determination of phosphorus}

One gram of dry matter was weighed into $50 \mathrm{ml}$ beakers, followed by an addition of $10 \mathrm{ml}$ mixture of analytical grade acids $\mathrm{HNO}_{3}: \mathrm{HCIO}_{4}$ in the ratio of $5: 1$. The digestion was performed at a temperature of about $190{ }^{\circ} \mathrm{C}$ for $1.5 \mathrm{~h}$. After cooling, the solution was made up to a final volume $(30 \mathrm{ml})$ with distilled water in a volumetric flask. Phosphorus was measured calorimetrically by ascorbic acid method using a Varian spectrophotometer. Analysis of each sample (on a dry matter basis) was carried out three times to obtain representative results.

\section{Digestion and determination of Arsenic}

The total plant As concentration was determined digesting the plant sample $(1 \mathrm{~g})$ with concentrate $\mathrm{HNO}_{3}$ and 2 hours after cooling $2 \mathrm{ml}$ of $\mathrm{H}_{2} \mathrm{O}_{2}$ was added in the solution. Total As concentration of extract was determined by hydride generation- using a VARIAN model AA2407 Atomic Absorption Spectrophotometer (AAS). Analysis of each sample was carried out three times to obtain representative results and the data are reported in $\mathrm{mg} \mathrm{kg}^{-1}$ (on a dry matter basis). 


\section{Statistical analysis}

The experiment was designed in completely randomized (CRD) with 7 treatments and three replications. Treatment effects were determined by analysis of variance with the help of statistical package MSTAT-C and mean separation was tested by Duncan's Multiple Range Test (DMRT). Linear correlation coefficients were also computed for various parameters using Microsoft Excel.

\section{Results and Discussion}

Despite the effect of $\mathrm{P}$ the As concentrations of shoot and root of maize increased with increasing As addition to soil (Figures-1 and 2). In both the year 2010 and 2011, the lowest As concentration was observed with the $\mathrm{As}_{0} \mathrm{P}_{0}$ treatment and the highest As concentration with the $\mathrm{As}_{30} \mathrm{P}_{60}$ treatment which was identical with $\mathrm{As}_{30} \mathrm{P}_{30}$. Arsenic concentration of root was much higher than that of shoot.



Fig. 1. Total As concentration in roots and shoots of maize under different As and $P$ application in soil - 2010.

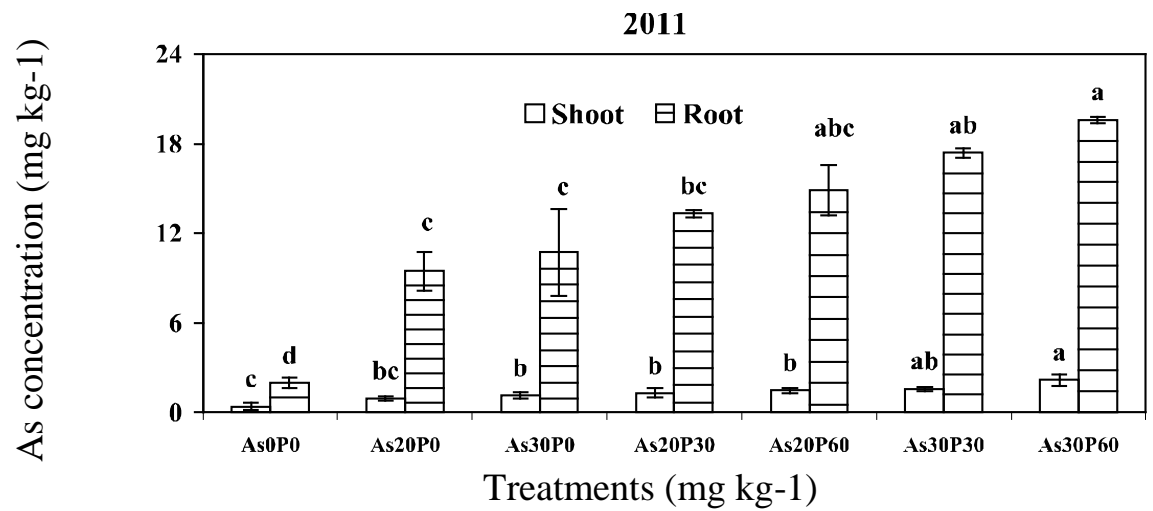

Fig. 2. Total As concentration in roots and shoots of maize under different As and $P$ application in soil - 2011.

The treatment column in specific line item with the same letter is not significant different $(\mathrm{P}<0.01)$ by DMRT. 
Comparatively P concentration of shoot was higher than that of root. Phosphorus containing treatments showed significantly higher $\mathrm{P}$ concentrations than that of without $\mathrm{P}$ in both shoots and roots (Figures-3 and 4). Contrary to normal understanding that increasing $\mathrm{P}$ supply could reduced As accumulation in plants, results from the present study showed that $\mathrm{P}$ fertilization did not inhibit the As uptake by plants (As accumulation in root and shoot). The effect of applied $\mathrm{P}$ was the opposite, the higher As concentrations in both shoot and root was observed in $\mathrm{P}$ treatments $\left(\mathrm{AsP}_{30}\right.$ and $\left.\mathrm{AsP}_{60}\right)$. Similar result was observed by Hossain et al. (2009). In contrast, the highest shoot As concentration $\left(2.45 \mathrm{mg} \mathrm{kg}^{-1}\right)$ was measured in the plants grown in As contaminated soil in the absence of $\mathrm{P}$ fertilization reported by Pigna et al. (2010). To alleviate As toxicity, plants must take up sufficient amount of $\mathrm{P}$ to balance excessive As. Thus, as plant As increases, the plants react by increasing $\mathrm{P}$ accumulation (Burlo et al. 1999).

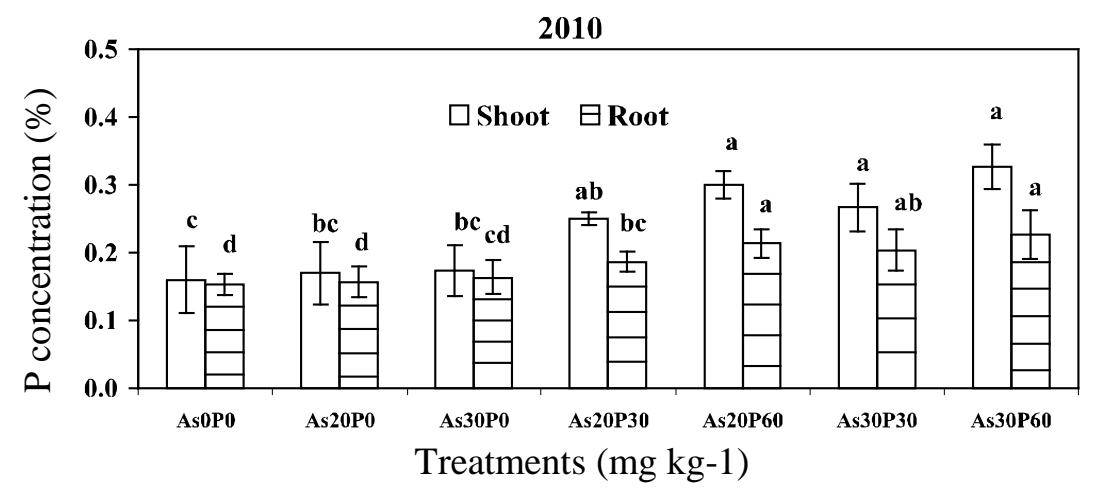

Fig. 3. Total $P$ concentration in roots and shoots of maize under different $A$ s and $P$ application in soil - 2010.

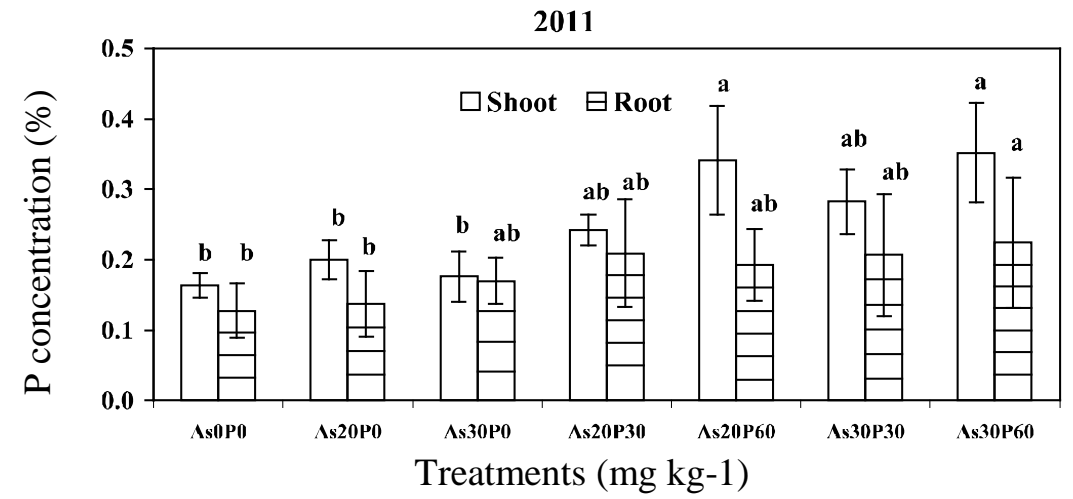

Fig. 4. Total $P$ concentration in roots and shoots of maize under different $A$ s and $P$ application in soil - 2011.

The treatment column in specific line item with the same letter is not significant different $(\mathrm{P}<0.01)$ by DMRT. 
The As concentrations in shoot and root and $\mathrm{P}$ concentration in shoot and root were positively correlated $(r=0.913, P<0.01 ; r=0.975, P<0.01)$ and $(r=0.994$, $P<0.01 ; r=0.800, P<0.05$ ) in 2010 and 2011, respectively (Figures -5 and 6 ). As expected, in this study both the year 2010 and 2011 plant As was positively correlated to the plant $\mathrm{P}$ in shoot $(r=0.883$ and $r=0.875 ; P<0.01)$ and in $\operatorname{root}(r$ $=0.829, P<0.05$ and $r=0.917 ; P<0.01$ ) (Figure-7a, $7 \mathrm{~b}$ and $8 \mathrm{a}, 8 \mathrm{~b}$ ) and the plants took up much greater amounts of $\mathrm{P}$ than $\mathrm{As}\left(\mathrm{P}\right.$ in $\% \times 10000=\mathrm{P}$ in $\left.\mathrm{mg} \mathrm{kg}^{-1}\right)$. Our results are in agreement with those reported in previous studies (Cao and $\mathrm{Ma}$, 2004).

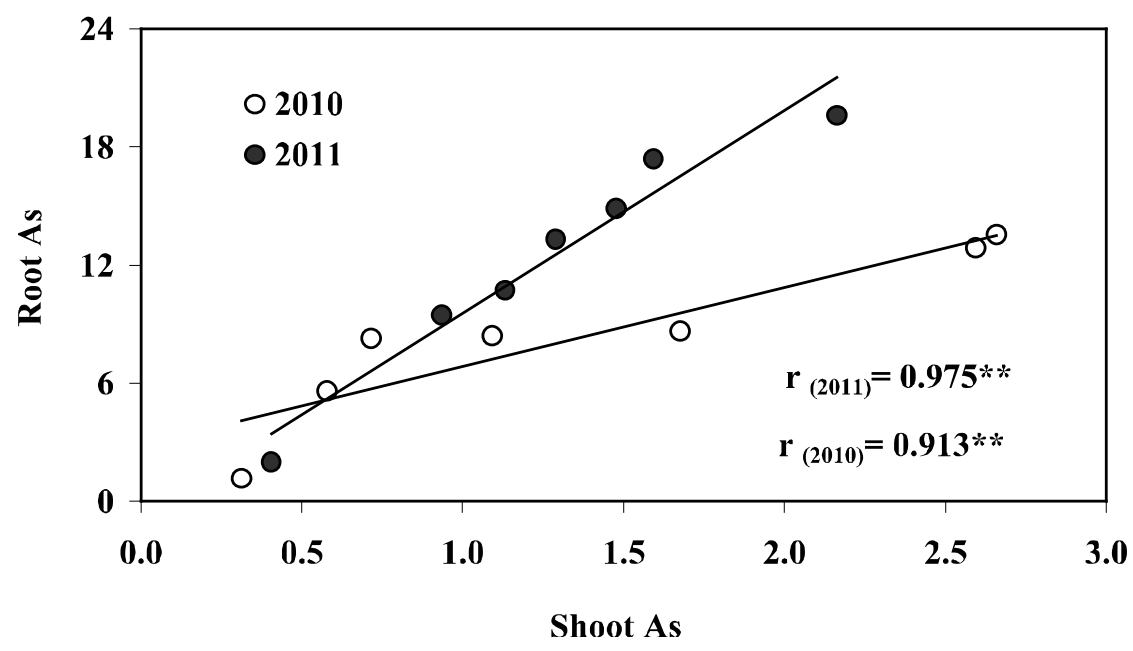

Fig. 5. Correlation of As concentration (mg kg-1) between roots and shoots of Maize.

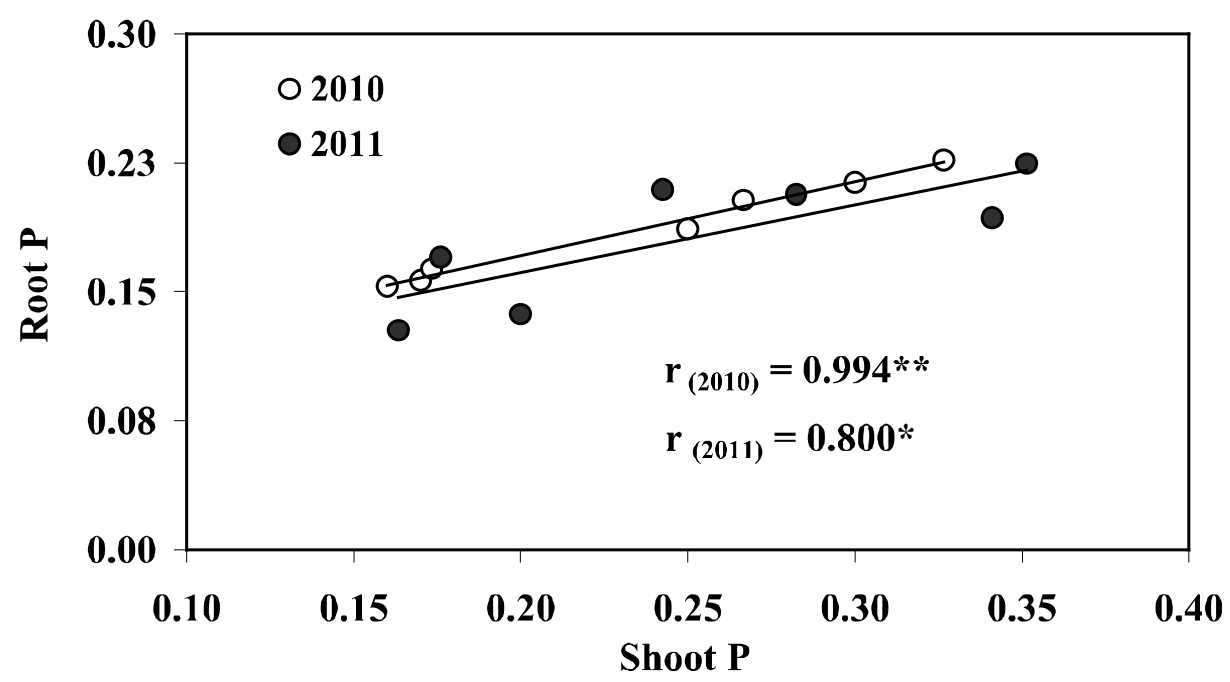

Fig. 6. Correlation of $P$ concentration (\%) between roots and shoots of Maize. 
Phosphorus addition $\left(\mathrm{P}_{30}\right)$ to As concentration increased in maize plants was 40 $54 \%$ and $29-37 \%$, respectively in 2010 and 2011 . Where as it was $50-55 \%$ and $37-47 \%$, for phosphorus addition $\left(\mathrm{P}_{60}\right)$, respectively in 2010 and 2011. Cao and $\mathrm{Ma}$ (2004) reported that addition of $\mathrm{P}$ to soils increased As accumulation by 4.569.3 times for carrot and 2.45-10.1 for lettuce plant.

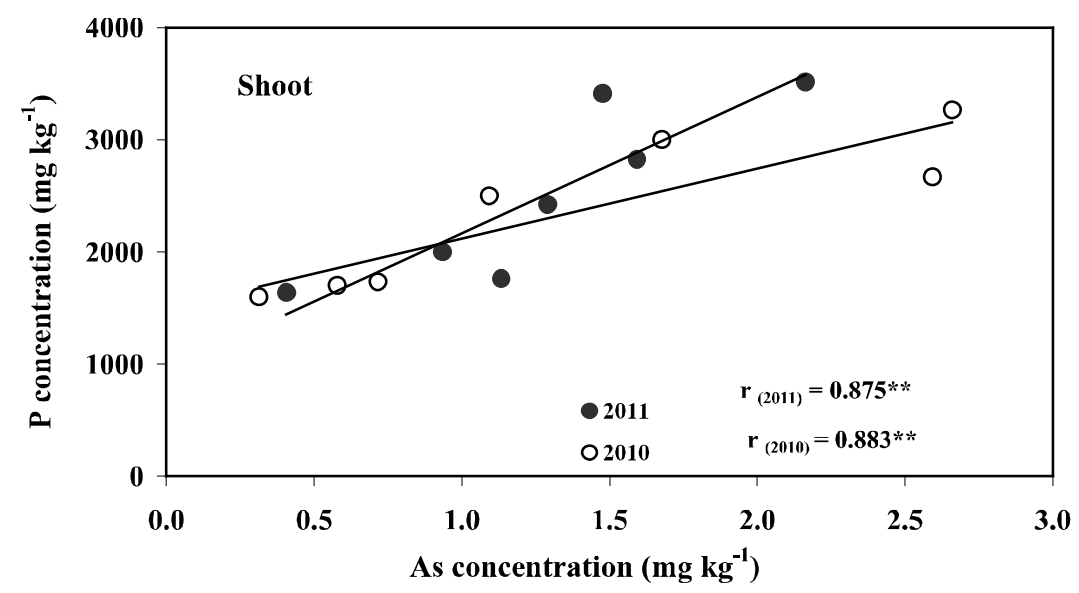

Fig. 7. Correlation between As and $P$ concentration in shoot of maize.

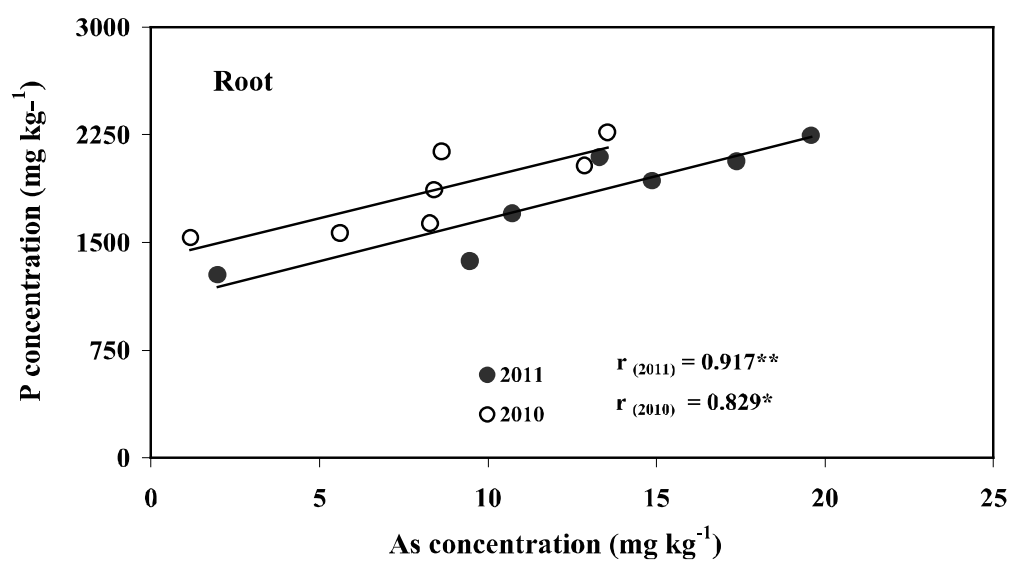

Fig. 8. Correlation between As and $P$ concentration in root of maize.

Figures 1 and 2 show the As partitioning in maize plant tissues for 2010 and 2011. In $-\mathrm{P}$ plants for the highest As concentration in $\mathrm{As}_{30}$ treatment was found to be $92 \%$ in root and $8 \%$ in shoot; whereas in $+\mathrm{P}$ plants, at the same As concentration, $84 \%$ was in the root and $16 \%$ in shoot. For the year 2011 it was $90 \%$ and $10 \%$ in root and shoot, respectively both in $-\mathrm{P}$ and $+\mathrm{P}$ plants. Results indicate that regardless $\mathrm{P}$ treatment, most of As accumulated in maize plant tissues, remains in root and the smallest amount in the shoot. In fact, $\mathrm{P}$ fertilization increased total As uptake, but the increase was restricted to the root. 
Similar result was observed by (Pigna et al. 2009). In wheat plants, Pigna et al. (2009) also observed that a very large amount of As (72\%) retained in root compared to its content (28\%) in shoot (straw and grain). Moreover, Abedin et al. (2002) also observed that a very large amount of As retained in root compared to its content in straw and grain. Other literature studies (Rahman et al. 2007) also reported similar results.

Arsenic exists in the environment in both inorganic and organic forms, and both arsenite (III) and arsenate (V) are often found in both anaerobic and aerobic soil environments (Liu et al., 2004). Although it is well known that phosphate inhibits arsenate uptake (Wang et al. 2002), this was not the case for this work. In the experiments showed, it is highlighted the role of $\mathrm{P}$ fertilization to increase As uptake in maize plants. Phosphate can decrease or increase the uptake of As by plants, depending on the speciation of As, the species of plant and the plant growth medium (Tsutsumi, 1980; Otte et al. 1990). Moreover, phosphate addition to arsenic-contaminated soils would enhance arsenic release from soil through competitive exchange (Smith et al. 2002), thereby increasing soil As availability (Peryea and Kammereck, 1997). Arsenic phytoavailability primarily depends on soil properties. Iron and aluminum oxides adsorb As species in acidic soils, whereas calcium oxides adsorb As species in alkaline soils (Wauchope and McDowell, 1984). However, the quantitative relationships between $\mathrm{P}$ nutrition, and As accumulation both arsenite and arsenate in maize plants remain unclear, and further investigation is warranted.

\section{Conclusion}

Phosphorus fertilization increased total As uptake in maize plant, but the increase was restricted to the root. The results presented here indicate $\mathrm{P}$ supply may effect in higher As allocation to the plant parts, which has practical application in soilcrop systems (Pigna et al., 2010). These findings could have important implications for human health and agricultural systems, since it may reduce As contamination through the consumption of crops grown on contaminated soils. Maize (Zea mays L.) is a widely grown staple cereal with promising attributes of the potential for accumulating toxic heavy metals and metalloids like As. The potential use of this robust tropical crop in phytoextraction technology is advocated especially for environmental restoration.

\section{References}

Abedin, M.J., Cresser, M.S., Meharg, A.A., Feldmann, J., Cotter-Howells, J. 2002. Arsenic accumulation and metabolism in rice (Oryza sativa L.) Environ. Sci. and Technol. 36: 962-968.

Burlo, F., Guijarro, I., Barrachina, A.A.C., Vlaero, D., 1999. Arsenic species: effects on uptake and accumulation by tomato plants. J. Agric. Food Chem. 47: 1247-1253. 
Cao X. and Ma L. Q. 2004. Effects of compost and phosphate on plant arsenic accumulation from soils near pressure-treated wood. Environmental Pollution 132 (2004) 435-442.

Dixon HBF. 1997. The biochemical action of arsenic acids especially as phosphate analogues. Advances in Inorganic Chemistry 44: 191-227.

Gultz, P.A., Gupta, S., Schulin, R. 2005. Arsenic accumulation of common plants from contaminated soils. Plant Soil 272: 337-347.

Hossain M. B., Jahiruddin M., Loeppert R. H. Panaullah, G. M., Islam M. R. and Duxbury J. M. 2009. The effects of iron plaque and phosphorus on yield and arsenic accumulation in rice. Plant Soil (2009) 317: 167-176

Jorge A.G. Santos, Maria I. Silva Gonzaga, Lena Q. Ma. 2010. Optimum P levels for arsenic removal from contaminated groundwater by Pteris vittata L. of different ages.Journal of Hazardous Materials. 180: 662-667

Liu W.J., Zhu Y.G., Smith F. A. and Smith S. E.2004.Do phosphorus nutrition and iron plaque alter arsenate (As) uptake by rice seedlings in hydroponic culture? New Phytologist. 162 : 481-488 www.newphytologist.org

Meharg, A.A., Macnair M.R. 1992. Suppression of the high affinity phosphate uptake system a mechanism of arsenate tolerance in Holcus lanatus L. Journal of Experimental Botany 43: 519-524.

Otte ML, Dekkers MJ, Rozema J, Broekman RA. 1991. Uptake of arsenic by Aster tripolium in relation to rhizosphere oxidation. Canadian Journal of Botany 69: 2670-2677.

Peryea, F.J. 1998. Phosphate starter fertilizer temporarily enhances soil arsenic uptake by apple trees grown under field conditions. Hort. Sci. 33: 826-829.

Peryea, F.J., Kammereck, R., 1997. Phosphate-enhanced movement of arsenic out of lead arsenate-contaminated topsoil and through uncontaminated subsoil. Water, Air, Soil Pollut. 93: 243-254.

Pigna M., Cozzolino1, V., Giandonato Caporale A., Mora M.L., Meo V. Di., Jara A.A., and Violante A. 2010. Effects of phosphorus fertilization on arsenic uptake by wheat grown in polluted soils. J. Soil Sci. Plant Nutr. 10(4): 428- 442.

Pigna, M., Cozzolino, V., Violante, A., Meharg, A.A. 2009. Influence of phosphate on the arsenic uptake by wheat (Triticum durum L.) irrigated with arsenic solutions at three different concentrations. Water Air Soil Pollut. 197: 371-380.

Rahman, M.A., Hasegawa, H., Rahman, M.M., Rahman, M.A., Miah, M.A.M. 2007. Accumulation of arsenic in tissues of rice plant (Oryza sativa L.). Chemosphere 69: 942-948.

Smith, E., Naidu, R., Alston, A.M. 1998. Arsenic in the soil environment: a review. Adv. Agron. 64: 149-195.

Smith, E., Naidu, R., 1998. In: Sparks, D.L. (Ed.), Arsenic in the soil environment: a review, Adv. Agronomy 64: 149-195. 
Smith, E., Naidu, R., Alston, A.M., 2002. Chemistry of inorganic arsenic in soils. II. Effect of phosphorus, sodium, and calcium on arsenic absorption. J. Environ. Qual. 31: 557563 .

Tsutsumi M. 1980. Intensification of arsenic toxicity to paddy rice by hydrogen sulphide and ferrous iron I. Induction of bronzing and iron accumulation in rice by arsenic. Soil Science and Plant Nutrition. 26: 561-569.

U.S. Environmental Protection Agency (Ed.), 1992. Mercury and Arsenic Wastes: Removal, Recovery, Treatment, and Disposal. Noyes Data Corporation, Park Ridge, NJ, Pp. 127.

Wang, J.R., Zhao, F.J., Meharg, A.A., Raab, A., Feldmann, J., McGrath, S.P., 2002. Mechanisms of arsenic hyperaccumulation in Pteris vittata. uptake kinetics, interactions with phosphate, and arsenic speciation. Plant Physiol. 130: 1552-1561.

Wauchope, R.D., McDowell, L.L., 1984. Adsorption of phosphate, arsenate, methanearsonate, and cacodylate by lake and stream sediments: comparisons with soils. J. Environ. Qual. 13: 499-504.

Williams, P.N., Price, A.H., Raab, A., Hossain, S.A., Feldmann, J., Meharg, A.A. (2005). Variation in arsenic speciation and concentration in paddy rice related to dietary exposure. Environ. Sci. and Technol. 39: 5531-5540. 